Åse Markussen

Independent Scholar

\title{
Hvem var Olaf Malm? Er det levende modeller bak denne figuren i romanen Fra Piazza del Popolo av Vilhelm Bergsøe?
}

\author{
Who was Olaf Malm? Are There Living Models behind This Character \\ in the Novel Fra Piazza del Popolo by Vilhelm Bergsøe?
}

Based on the Nordic sculptor community in Rome around 1860, the article discusses candidates that served as inspiration for the fictional Olaf Malm from Telemark, the protagonist in the chapter "Malms historie" in Vilhelm Bergsøe's key novel Fra Piazza del Popolo (1866). Some of the clues in the text are Malm's sculptural works. A study of different sources and earlier research together with the candidates' personality, biography, and travel patterns point in a new direction and strengthen the probability of the Norwegian sculptor Hans Johnsen Budal as being the main model, whereas some traits hint at the Danish sculptor Herman W. Bissen. The candidacy of the sculptor Olaf Glosimodt, which is established in Norway, however, is no longer credible.

Key words: Nordic late classical sculpture, Rome, Key novel, Hans Johnsen Budal, Herman W. Bissen

Nøkkelord: Nordisk senklassisistisk skulptur, Roma, Nøkkelroman, Hans Johnsen Budal, Herman W. Bissen

Den danske forfatter og zoolog Vilhelm Bergsøe (1835-1911) skrev sin kjente nøkkelroman Fra Piazza del Popolo. Livsbilleder samlede i Rom (1866) med utgangspunkt i et opphold i Roma fra 1862 til 1863, og viet hele 69 sider til fortellingen om Olaf Malm, en norsk billedhugger fra Telemark, og hans kamp for kunsten og kjærligheten. «Malms historie» er lagt til tiden rundt 1830, men det er sannsynlig at forfatteren hentet sin inspirasjon fra det nordiske billedhuggermiljøet han møtte i Roma i begynnelsen av 1860-årene. Deler av teksten er dermed av skulpturhistorisk interesse. Mange har fattet interesse for «Malms historie», også den norske litteraturhistorikeren Harald Bache-Wiig i Studia Scandinavica i 2018. 
Romanens karakter av nøkkelroman ${ }^{1}$ åpner for en drøftelse av miljøskildring og personer, både i deres fiktive romankontekst og som mulige referanser til faktiske personer. Bokens grad av faktisitet er riktignok vekslende, men flere av nøkkelpersonene kan gjenkjennes i forfatterens egen omgangskrets ${ }^{2}$.

Min hensikt med denne artikkelen er å drøfte hvorvidt romanskikkelsen Olav Malm speiler en faktisk nordisk billedhugger. Jeg trekker inn tidligere forskning og erindringslitteratur, der Hans Johnsen Budal, Olaf Glosimodt, Frithiof Kjellberg, Ole Fladager og C.F. Holbech er foreslått som modeller for Malm. Jeg inkluderer også Herman W. Bissen i undersøkelsen, som kort omfatter disses biografi, kunstnerskap, personlighetstrekk og tidspunkt for opphold i Roma.

Om gjennomgangen av Malms skulpturer i fortellingen vel ikke gir noe svar på gåten, kaster den i det minste et visst lys på det nordiske billedhuggermiljøet i Roma og Bergsøes kontakter der. Som kunsthistoriker ligger min interesse altså like mye på stoffets skulpturhistoriske implikasjoner som på det litterære.

\section{Bergsøes roman}

Fra Piazza del Popolo ble tidlig en av Danmarks mest leste romaner, og er i dag trykt i over 200000 eksemplarer. I andre utgave fra 1870 endret forfatteren undertittelen til Novelle-Cyklus, noe som passer til formen av rammefortelling med syv fortellinger knyttet tematisk sammen i en kompleks komposisjon. Boken kalles gjerne roman, men litteraturhistorikeren Gunhild M. Agger viser til at den også plasserer seg i helt sentralt i dansk fortellingstradisjon. Spillet og spenningen i verket fungerer godt nettopp fordi det er oppbygd av fortellinger i ulike genre (melodrama, røverhistorie, skjebnefortelling og annet) (Agger 1994: 119ff). Handlingen utspilte seg i Italia og på Sjælland i Danmark i tiden rundt den store koleraepidemien i 1853 og tiden rundt 1830. Rammens nåtid er tidlig i 1860-årene.

Formen skyldes kanskje bokens særegne tilblivelse. Da Bergsøe besøkte Italia det knappe året 1862-1863, var det som rekonvalesent etter en alvorlig øyensykdom. I 1864 avla han sin doktorgrad i zoologi «med ære» i København, men ble så angrepet av en invalidiserende giktfeber, og nok en gang nesten blind. I 11

1 «Nøgleroman kalder man en Roman, der menes at være fuld af Hentydninger til eller Karakterbilleder af bestemte Personligheder, hvilket saa, naar Romanen vækker Opsigt [...], giver Anledning til, at ingeniøse og sladderlystne Personer leverer en Nøgle: en Angivelse af de Personer, til hvilke der formentlig er hentydet. Den virkelig kunstneriske Fantasi lader sig vel rigelig inspirere af Oplevet Virkelighed, men arbejder ikke med en saadan nøgtern Portræteren af bestemte Modeller; den forbinder Karaktertræk, der er hentede fra forsk. sider, til en ny Skikkelse, omformer og omdigter; Nøglen er i Alm. Laget og misvisende, og Forfatteren af Romanen har Ret til at tilbagevise ell. Ignorere Sladderen». Den danske sosiologen og filosofen Cladius Wilkens (1844-1929) i Salmonsens Konversationsleksikon (1924).

2 Nøkkelpersonene drøftes i Flemming Conrad og Lars Peter Rømhilds Efterskrift i nyutgivelsen av Fra Piazza del Poplo fra 1988 (Bergsøe 1988: 565ff). 
måneder lå han i et mørkt rom, sterkt medisinert. Nærmest ved en tilfeldighet ble han av forleggeren P.G. Philipsen bedt om å skrive noe fra sin reise i Italia. Dermed dikterte den syke Bergsøe til ulike besøkende de fortellingene som skulle danne Fra Piazza del Popolo. Bokens tilblivelse er grundig beskrevet av Hermann Peter Rohde i 1972, og vil ikke bli ytterligere berørt her.

Rammefortellingen begynner om aftenen den 1 . mai ved obelisken på Piazza del Popolo i Roma, der en gruppe skandinaver var samlet (ill. 1). En av hovedpersonene inngikk et overmodig veddemål om å gå en aftentur utenfor bymurene gjennom «røverland» til Ponte Milvio, og komme uskadd tilbake innen byporten stengte for natten. Romas omegn var farlig, og han ble snart kidnappet av røvere som krevde løsepenger. Mens dagene gikk og vennene engstelig ventet, fortalte de historier. Likheten med Boccaccios Decameronen er åpenbar og villet, men Bergsøes bok har en fastere romanform. Den kidnappede dukket mirakuløst opp igjen den sjette dagen, mens rammefortellingen først ble avsluttet noe senere.

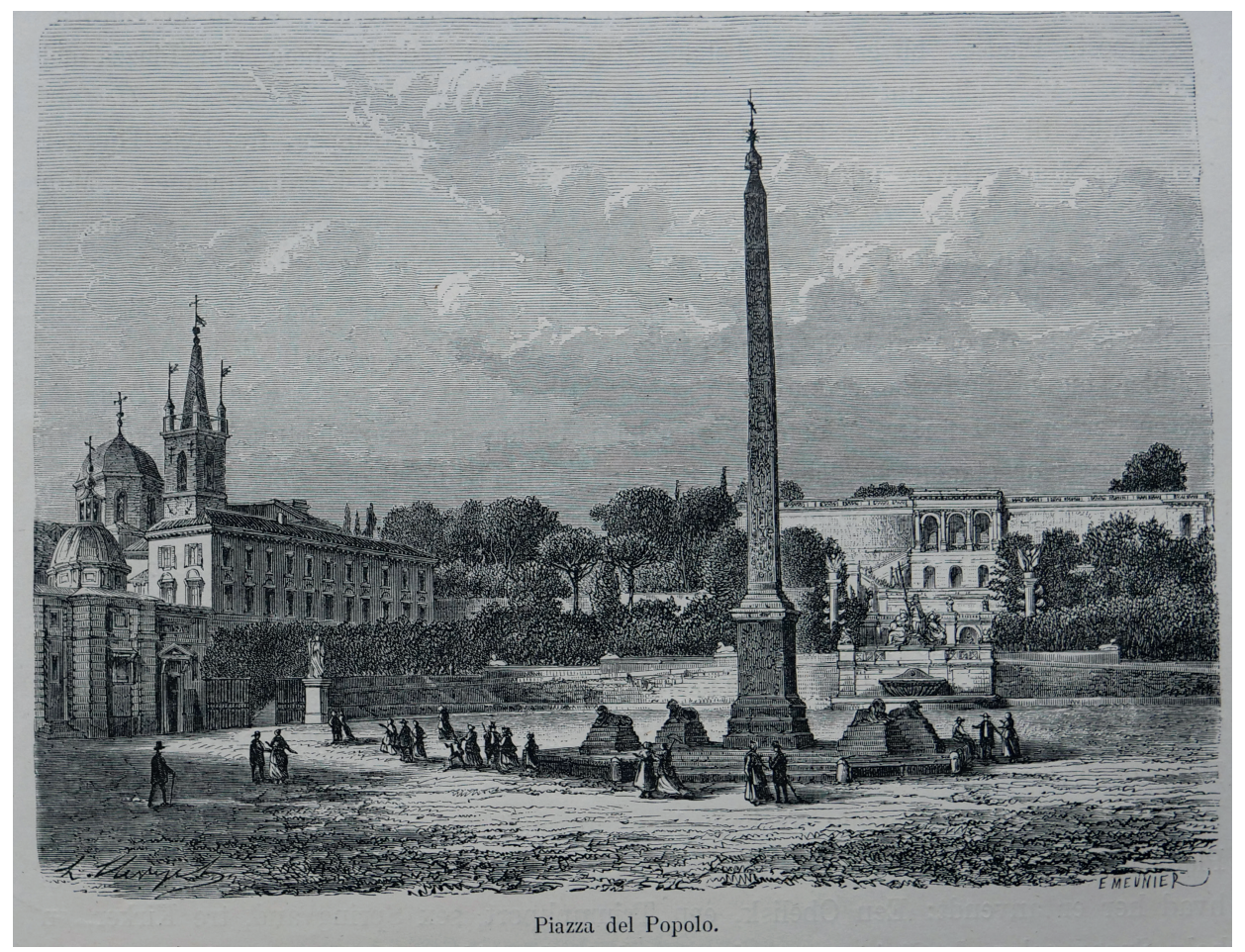

Illustrasjon 1. Ukjent kunstner, Piazza del Popolo, u.å., tresnitt etter tegning (foto: C. Bjørnaraa)

Kilde: Bergsøe 1877: 217.

Jeg kommer tilbake til «Malms historie», men først en kort presentasjon av det nordiske billedhuggermiljøet i Roma i tiden rundt Bergsøes besøk i 1862-1863. 


\section{Billedhuggerne og Roma}

Ved midten av 1800-årene var innflytelsen fra Bertel Thorvaldsens (1770-1844) nyklassisisme fortsatt sterk i Roma. Hans elev Herman W. Bissen (1798-1868) var professor på kunstakademiet i København fra 1840, og påvirket der en hel generasjon billedhuggere i samme retning. De fleste i den nordiske kolonien hadde vært Bissens elever og assistenter. I Roma møtte denne generasjonen idealene fra antikken og nyklassisismen, men mottok i liten grad impulser utenfra. De arbeidet i den romerske senklassisismens høst, en blindgate sett i forhold til den samtidige utviklingen mot en realistisk skulptur i andre europeiske land som Frankrike ${ }^{3}$.

Det sier noe om tyngden av det romerske skulpturmiljøet under senklassisismen at Bergsøe valgte å skrive et langt kapittel om en billedhuggers skjebne. Roma var billedhuggernes by. De nordiske tilreisende kunne riktignok oppleve det første møtet med den antikke skulpturskatten som lammende. Martinus Galschiøt, Skandinavisk forenings bibliotekar fra 1873 til 1875, skrev i sine erindringer fra Roma om «den Modløshed som de fleste unge Billedhuggere gribes af i deres første Romertid, overvældede som de er, af al den Kunstens Rigdom og Herlighed, som de paa en Gang kommer til at staa overfor» (Galschiøt 1925: 185).

Det var 11 nordiske billedhuggerne i Roma da Bergsøe ankom før jul i 1862. De danske var i flertall, med Herman W. Bissen og sønnen Vilhelm, Carl Hartmann, Carl Frederik Holbech, Lauritz Prior og August Saabye. De øvrige var de svenske Axel Cantzler og Frithiof Kjellberg, den finske Walter Runeberg og de norske Hans Johnsen Budal og Ole Henriksen Fladager. En tredje nordmann, Olaf Olafsen Glosimodt, hadde reist fra Roma noe før Bergsøe ankom.

Den norske kunsthistorikeren Lorentz Dietrichson kom også til Roma i slutten av 1862, og ble sekretær og bibliotekar i Skandinavisk forening fra mai 1863. I erindringsboken Svundne Tider har han gitt en miljøskildring av den nordiske kolonien i osteriet Palombella på vårparten i 1863 (Dietrichson 1901: 41), og vi finner alle Malms «kandidater» på plass, unntatt Glosimodt. Dietrichson fremhevet koloniens to nestorer Bissen og Holbech; den siste satt benket sammen med Ole Fladager og Hans Budal. Disse to norske var med Dietrichsons ord Holbechs «trofaste Fæller fra 'Dydsforeningen'», en uformell gruppe skandinaver som gjerne møttes i osteriet Chiavica del Bufalo, og som er beskrevet i Meir Goldschmidts Hvorledes man lever i Rom fra 1863 (Goldschmidt 1863: 22ff). Også «Digteren Bergsøe» var til stede i Palombella denne dagen, sammen med et titalls andre nordboer, blant andre svenske Frithiof Kjellberg.

I 2002 viet Thorvaldsens Museum utstillingen Afmagt til den splittelsen som generasjonene etter Thorvaldsen opplevde i spriket mellom arven fra Thorvaldsen og realismen som utviklet seg i skulpturen i siste halvdel av 1800-tallet. 


\section{Geografi og biografi}

De fleste nordiske tilreisende bodde og arbeidet i «den skandinaviske trekanten», også kalt «fremmedkvarteret», området mellom Piazza del Popolo, Piazza di Spagna og Piazza Barberini. De møttes på osterier og kafeer i nabolaget, fra 1860 også i Skandinavisk forening, stiftet samme år. Bergsøe selv bodde først i Hotel Caffè Greco i Via dei Condotti, og senere i Via Sistina.

Veteranen i miljøet var den danske Thorvaldsen-eleven Holbech (1811-1880), fastboende i Roma fra $1841 \mathrm{og}$ livet ut. Han var med sin kraftige skikkelse og lange hår og skjegg en kjent person i byen (ill. 2), og et samlingspunkt for skandinavene. Man omtalte ham spøkefullt som "president» for den ovennevnte «Dydsforeningen». Han bodde ved Piazza Barberini, mens atelieret lå i Via di San Basilio 43 rett i nærheten. Holbechs kunstneriske produksjonen var liten, vi kjenner i dag bare tre mindre skulpturer i danske samlinger. Bergsøe beskrev Holbech og Budal som venner i erindringsboken Eventyr i udlandet fra 1905, og Budal skal ha fătt arbeide i Holbechs atelier (Bergsøe 1905: 206).

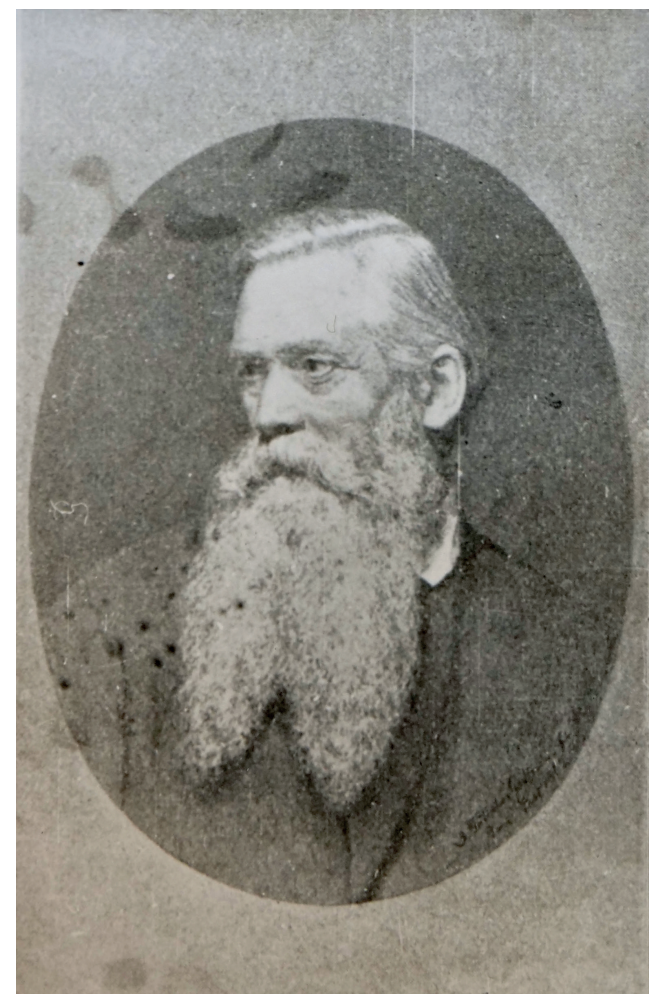

Illustrasjon 2. Billedhuggeren C.F. Holbech (foto: C. Bjørnaraa)

Kilde: Bergsøe 1905: 133. 
I følge en notis i Morgenbladet ([Notis] 1861) kom Hans Budal til Roma sammen med telemarkingen Olaf Glosimodt sist i oktober 1861, begge to med statsstipend: «Det vil uden Tvivl interessere at erfare, at vore 2de haabefulde Kunstnere, Billedhuggerne Glosimodt og Budal, ere komne til Rom, i de sidste Dage af forrige Maaned efter en 3 Ugers Reise, hvorunder de have opholdt sig nogle Dage i Berlin, Dresden og München». Vennen Ole Fladager hjalp dem til rette i byen, og nevnte dem i et reisebrev fra Roma til Morgenbladets lesere den 27. november 1861.

Hans Johnsen Budal (1830-1879) kom fra gården Plasshauom i Budalen i Sør-Trøndelag. Familien var haugianere (Dørum 2021). Han lærte treskjæring av sin far, og hans talent ble oppdaget av Christiania kunstforenings Emil Tidemand på en reise gjennom Budalen ([Notis] 1871). En innsamling blant kunstinteresserte i Christiania hjalp Hans til utdannelse ved Tegneskolen i Christiania som ganske ung. Senere gikk han på akademiet i København under professor Jens A. Jerichau, og vant akademiets sølvmedaljer i 1855 og 1856 . Det ble sagt om ham at han eide et usedvanlig talent og en dyp, inderlig kunstoppfatning, men hadde lett for å tvile på egne evner. I sin første tid i Roma studerte han byens kunstsamlinger, og skrev hjem at «man nesten blir overveldet derav i førstningen» ${ }^{4}$. Han kom da heller ikke riktig i gang. Først i 1863 fikk han sendt hjem to arbeider, en kopi av en av Niobes døtre i marmor og en Ung pike som steller håret i gips. Begge er i dag i Nasjonalmuseet i Oslo. Budal ble hele ti år i Roma, og hadde perioder da han var syk, uvirksom og i stor pengenød. Men de to første årene og under Bergsøes besøk må han ha klart seg ganske godt med de 800 spesidaler han hadde med seg i stipend og private bidrag fra Norge. Olaf Glosimodt (1821-1901) var elev av Bissen på akademiet i København, og vant akademiets to sølvmedaljer i 1854 og 1857. Under sitt korte opphold i Roma laget han Nasjonalmuseets portrettmedaljong av Bjørnstjerne Bjørnson.

Svenske Frithiof Kjellberg (1836-1885) arbeidet sammen med Runeberg og Prior i Via di San Basilio 18, tvers over gaten for Holbech (og Budal). Deres tre atelierer vendte inn mot en idyllisk hage med springvann og frosker, beskrevet både av Bergsøe og Dietrichson, og sannsynligvis forbildet for Malms første store atelier med hage (Dietrichson 1901: 65-66; Bergsøe 1905: 203-204). Kjellberg var i Roma fra 1862 til 1868. I 1863 modellerte han to fauner som jeg kommer tilbake til.

De danske Herman W. og Vilhelm Bissen hadde et stort atelier i Via dei due Macelli 24. «Gamle» Bissen hadde oppholdt seg i Roma i flere lange perioder. Han kom fra enkle kår i Slesvig, hadde et stort talent som ble oppdaget tidlig, og ble sendt til akademiet i København med privat understøttelse. Lysende begavet vant han akademiets lille gullmedalje i 1821, og senere i 1823 den nærmest uoppnåelige store gullmedalje med reisestipend til Roma. Dit ankom han i 1824 etter å ha gått til fots fra München over Alpene, sammen med maleren Ernst Meyer og sin lille hund (Rostrup 1945: 53ff). Herman W. Bissen var kraftig bygd og med lyse blå øyne, og utviste hele

$4 \quad$ Brev fra Hans Budal til familien, 1. november 1861, sitert etter (Bakken 1935: 595). 
livet en legendarisk energi og arbeidskraft. Han beskrives som rolig, beskjeden og tilbakeholden, men samtidig med et kolerisk temperament. I sitt tiårlange første romaopphold arbeidet han hos Thorvaldsen. Han var selvkritisk, og nærmest ydmyk i forholdet til antikkens kunst. I april og mai 1863 var han i Roma for å legge en siste hånd på marmorskulpturen Den vrede Achilles, en skulptur jeg kommer tilbake til. Et særtrekk ved både far og sønn Bissen var deres store interesse for planter og dyr. Da zoologen Bergsøe kom til byen, ble Vilhelm hans cicerone på campagnaen.

Ole Henriksen Fladager (1832-1871) var fra Valdres, og gikk etter Tegneskolen i Christiania på akademiet i København under professor Bissen. Han vant akademiets sølvmedaljer i 1855 og 1856, og kom til Roma med norsk statsstipend i 1858. Der fikk han arbeide i et mindre rom $\mathrm{i}$ «Due Macelli» hos vennen Vilhelm Bissen. Fladagers byste av historikeren Peter Andreas Munch ble utført i Roma i 1859. I 1863 arbeidet han på politikeren Jørgen H. Vogts byste. Begge er i dag i Nasjonalmuseet i Oslo.

Danske forskere har pekt på Budal og Holbech som modeller for Malm. Fladager og Kjellberg har også vært nevnt. Selv finner jeg interessante trekk hos «gamle Bissen». Som jeg kommer tilbake til, har det i Norge vært en etablert oppfatning at skikkelsen Olaf Malm bygger på telemarkingen Olaf Glosimodt.

\title{
4. «Malms historie»
}

\begin{abstract}
Det var en ung, temmelig høi Mand, klædt næsten fuldstændig i Thelemarkernes Dragt, med hvid, ulden Kofte, Knæbeenklæder og Lærbelte om Livet. Han havde et rigt mørkebrunt Haar, der var strøget glat tilbake og i naturlige Krøller faldt ham ned mod Skuldrene, en mægtig, bred Pande, en temmelig stor og noget krummet Næse, der tilligemed de stærke fastsluttende Linier rundt Munden gav ham et Udtryk af Kraft og Bestemthed. Det merkeligste, og hvad der strax slog mig med ham, var hans Øine, som stod i stærk Modsætning til hans brunette Hudfarve og næsten sortbrune Haar. De vare store, mørkeblaae, glansfulde og dog rolige i deres Udtryk, men det foer ligsom et Lyn fra dem (Bergsøe 1988: 90).
\end{abstract}

Historien om Malm er en mørk skjebnefortelling, lagt til Roma rundt 1830. Den ble fortalt på Piazza del Popolo ved obelisken på kidnappingsdramaets andre dag, Forteller var kretsens nestor, billedhuggeren «den Gamle Kunstner» eller «den Gamle af Dage», hvis utvilsomme modell var Roma-veteranen C.F. Holbech ${ }^{5}$.

I historiens innledende beskrivelse av Malm, sitert over, ser vi at han hadde et slående og godt utseende. Han var mandig, begavet, beskjeden, med en viss troskyldighet i karakteren og et heftig temperament. Det enkle hjemmet i Telemark var haugiansk, han lærte treskjæring av sin far, og hans store talent ble oppdaget av en tilreisende som hjalp ham til utdannelse. I Christiania vant han «baade første og anden Priisbelønning og endelig det store Legat til Romerreisen» (Bergsøe 1988: 99).

5 Bekreftet av forfatteren (Bergsøe 1905: 188-189). 
I vårt første møte med Malm fremgikk det at han hadde gått til fots deler av strekningen fra Telemark til Roma.

Malm kom til Roma med ambisjoner om å lage en stor skulpturgruppe av Gigantene stormer Olympen, og leide et av byens beste atelierer. Men han ble overveldet og mistet motet i møtet med Romas antikke kunst, og skulpturen ble aldri realisert. I stedet ville han reise hjem. «Jeg har ingen Planer mere; jeg duer ikke til Noget. Antiken har gjort Alt; jeg er overflødig» (Bergsøe 1988: 98). Under en avskjedstur til Nemisjøen ${ }^{6}$ i Albanerfjellene sørøst for Roma, traff han på vennen «den Gamle af Dage» og fortalte ham om en drøm han hadde hatt samme ettermiddag ved sjøens kilde. En vakker kvinne med gylden krone hadde kommet opp av tåkesløret over vannet og sagt ham at han kom til å skape et mesterverk for hver sten som han klarte å kaste over sjøen. Han hadde trodd det var en hulder og korset seg. «Det kan være, men saa har hun gjort en lang reise», svarte «den Gamle af Dage», og fortalte det gamle sagnet om Nemisjøen og nymfen Egeria. Hennes tårer hadde strømmet og strømmet da gudinnen Diana drepte hennes elskede Numa, de ble til kilden de satt ved og fylte snart hele det tidligere krateret. Egeria hersket over Nemisjøen, men skoggudinnen Diana ble også dyrket i det samme området (Bergsøe 1866: 148-150). Malm ble tenksom. Så kastet han én sten, så enda to, og alle tre nådde motsatt bredd. Det fjerde kastet mislyktes.

Nå ble Malm likevel i Roma, men arbeidet ikke. Da kollegene hånet ham for en uvirksom vinter, svarte han med et rasende utbrudd: «Ikke forlanger jeg at skaanes af Eder», raabte han med tordnende Stemme, «men ei heller vil jeg haanes af Hundehvalpe! Kom i morgen til mig, hvo der vil, og see saa, om Olaf Malm forstaaer at gjøre Noget» (Bergsøe 1988: 105). Så la han over natten opp en mesterlig skisse i leire av en faun som løfter sin lille sønn.

Inspirerte øyeblikk som dette gir personen Malm et romantisk skinn av geni og naturbegavelse. Han hadde perioder med livsglede og skaperkraft, men det er ofte mismot og passivitet som preger skikkelsen. Slik det ble spådd i drømmen ved Nemisjøen, skapte han tre mesterverk i Roma. De vakte alle stor oppsikt i miljøet, men alle tre ble slått ned, knust eller forlatt av ham selv. Blant billedhuggerne var han en fremmed fugl, kanskje mer begavet enn flertallet, men også mer utsatt, selvkritisk og tilbakeholden. «Den Gamle af Dage» var vennen som så Malms store talent, og som hjalp ham gjennom hele historien, både da han var på sultedødens rand og da hjertet ble knust av kjæresten Sigrid. I fortellingens dramatiske avslutning reddet Malm en fattig jødisk kvinne under en stor flom i Tiberen, men ble selv oppslukt av elvens frådende vannmasser ${ }^{7}$.

6 Lago di Nemi er en kratersjø i Albanerfjellene i Italia, cirka 25 kilometer sørøst for Roma. Innsjøen er et kultsted fra forhistorisk tid og var sentrum for kulten for jaktgudinnen Diana (romersk variant av den greske gudinnen Artemis) (Lindhagen 2020).

7 Da Bergsøe knyttet trådene i bokens nåtid 30 år senere, dukket Malm uventet og lys levende opp som den skulderbrede og edle fransiskanermunken Fra Ambrosius. Han hadde overlevd flommen, men oppgitt sin kunst og gått i kloster. Denne biten fra fortellingenes komplekse puslespill har 


\section{De tre stenene over Nemisjøen og Malms tre mesterverk}

De tre skulpturene Malm laget i Roma kan være nøkkel til Bergsøes inspirasjonskilder. Den første skulpturen var som nevnt en faun med sin lille sønn:

Faderens stærke, men dog smidige og muskuløse Figur danner en smuk Modsætning til Drengens runde, buttede Former, og det halvt forskrækkede, halvt glade Udtryk i dennes Ansigt tog sig fortræffeligt ud imod de barske og haarde Linier hos den skjæggede Vildmand (Bergsøe 1988: 106).

Under det videre arbeidet med faunen lot Malm seg påvirke av kollegenes velmente råd, og da han så at skulpturen var blitt overarbeidet, slo han den ned og stengte døren for kollegene. Idéen til dette må Bergsøe ha fått i Kjellbergs atelier. I 1863 modellerte Kjellberg en skulpturgruppe med to fauner, som senere ble hugget i marmor og i dag er i Nationalmuseum i Stockholm (ill. 3). Bergsøe forteller i sine erindringer:

dog vakte det stor Opsigt blandt Skandinaverne, da Kjellberg pludselig modellerede en Faun, som i Faderglæde, løfter sin nyfødte Søn i Vejret, et antikt Motiv for Resten, men af Kjellberg gjengivet paa en mesterlig Maade. Dessværre blev denne Figur aldrig færdig; thi da den først var klasket op i Leret og skulde gaas efter, fik Kjellberg saa mange gode Raad og saa mange Betænkeligheder, at Figuren lidt efter lidt vandrede gennem Jernstativet og en skønne Dag tog Plads paa Gulvet. Naar Malm i Fra Piazza del Popolo lukker sig inde for ikke at forstyrres af sine gode Venners Kritik, skyldes dette Historien om Kjellbergs Faun (Bergsøe 1905: 205-206).

Kjellbergs Faun lekande med sin yngre broder i Nationalmuseum i Stockholm viser ingen «skjæggede Vildmand», men en ung faun med sin lille bror. Den kan være en senere versjon, men jeg finner det mer sannsynlig at Bergsøe så den antikke skulpturen Silen med Dionysosbarnet (etter Lysippos) i Vatikanmuseene da han var i Roma, og smidig kombinerte den med Kjellbergs unge faun $i$ «Malms historie» (ill. 4). Vi ser at han i erindringene kalte motivet antikt.

imidlertid lite å bidra med når det gjelder identifiseringen av modeller for den unge Malm. «Malms historie» regnes som en lukket og komplett historie hvis naturlige avslutning var Malms drukningsdød i Tiberen. At Malm senere oppsto som munken Fra Ambrosius blir ikke nærmere forklart, og betraktes som et påhitt fra Bergsøe for å få fortellingene til å henge sammen (Rubow 1948: 15, 27). 


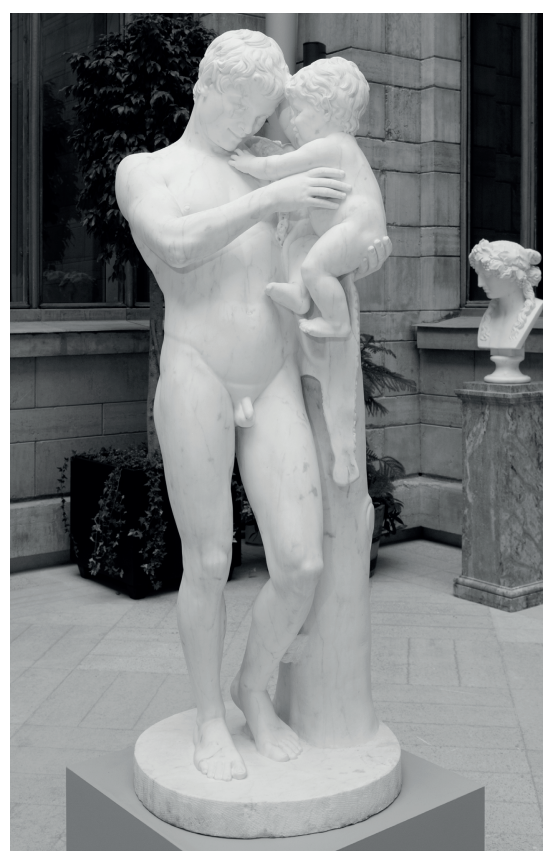

Illustrasjon 3. Frithiof Kjellberg, Faun lekande med sin yngre broder, u.å, marmor, høyde $150 \mathrm{~cm}$ (gipsmodell 1866) (foto: Linn Ahlgren/Nationalmuseum)

Kilde: Nationalmuseum.

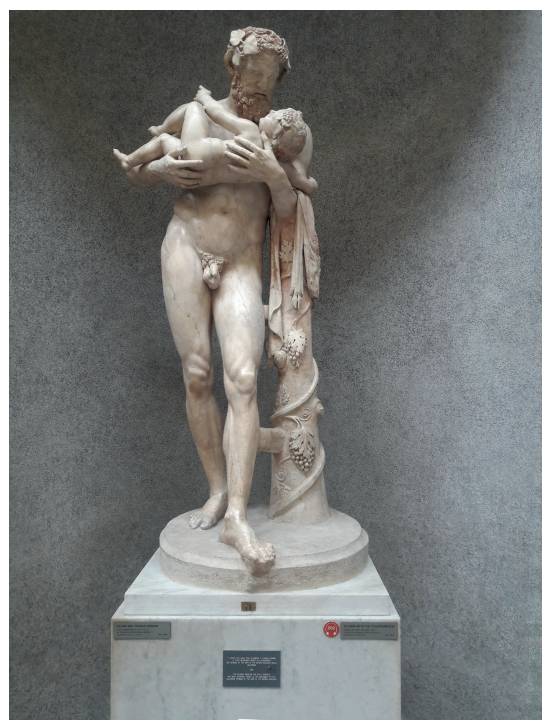

Illustrasjon 4. Silen med Dionysosbarnet (etter Lysippos), 2. årh. e.Kr., romersk kopi etter gresk original, marmor, høyde $190 \mathrm{~cm}$ (foto: Åse Markussen) Kilde: Musei Vaticani. 
Malms neste store verk var en Akilles,

som rasende over Briseis rov grunder paa Hævn mod Achæerne. Det var en siddende Figur uden Draperi, i omtrent halv overnaturlig Størrelse; Hjelm og Skjold laae ved dens Side og et brudt Sværd ved dens Fødder. [...] Det var en mægtig Figur, lige gribende i sin Lidenskab, hvad enten man saa hen til Ansigtets Udtryk eller til Holdningen (Bergsøe 1988: 112).

Figuren var ferdig modellert i leire og sto klar til å støpes i gips da Malm forlot den. Den danske kunstkritikeren Svingberg hadde klart å vinne hans tillit, for deretter å overtale ham til å forkaste antikkens «hedenske» kunstidealer og velge en kristen kunstideologi. Akilles tørket inn på kavaletten.

Slik Malms Akilles beskrives, må den være identisk med skulpturen Den vrede Achilles som Bissens modellerte i leire og støpte i gips i København i $1861^{8}$. Den ble senere hugget i marmor i Roma av sønnen Vilhelm fra høsten 1862 til våren 1863, da faren, som nevnt, selv kom et par måneder og la en siste hånd på verket. Bergsøe, som var omgangsvenn med Vilhelm Bissen under Romaoppholdet, må ha sett skulpturen under arbeid. En av dens to versjoner er i dag i Glyptoteket i København (ill. 5).

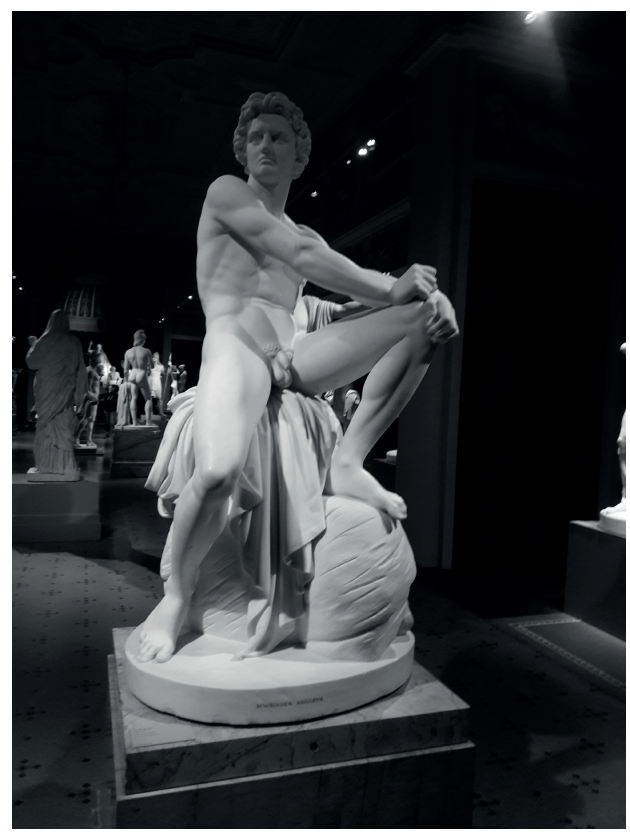

Illustrasjon 5. Herman Wilhelm Bissen, Den vrede Achilles, 1861/1863, marmor, høyde $174 \mathrm{~cm}$ (foto: Åse Markussen)

Kilde: Ny Carlsberg Glyptotek.

8 Motivet er hentet fra Iliadens 1. Sang: «Fnysende vred nu sad ved de lethenglidende Skibe / Peleus' Søn, hin Ætling af Zeus, fodrappen Achilleus [..]» (Rostrup 1945: 394-396). 
Malms tredje store verk var en Psyke i marmor med kjæresten Sigrids ansiktstrekk ${ }^{9}$. Malm ble syk av sorg og knuste skulpturen da Sigrid forlot ham for en annen. Motivet Psyke var ikke uvanlig. I 1833 så Hans Christian Andersen en «ganske deilig 'Psykke' i gibs» (Thorvaldsens Museum 2018) i Thorvaldsens atelier i Roma, og kan ha hatt den i tankene da han senere skrev novellen Psychen under sitt fjerde besøk i byen i 1861. Kanskje har Bergsøe lest novellen, som ble utgitt i 1862, og sett skulpturen i Thorvaldsens Museum, der den fortsatt er utstilt (ill. 6).

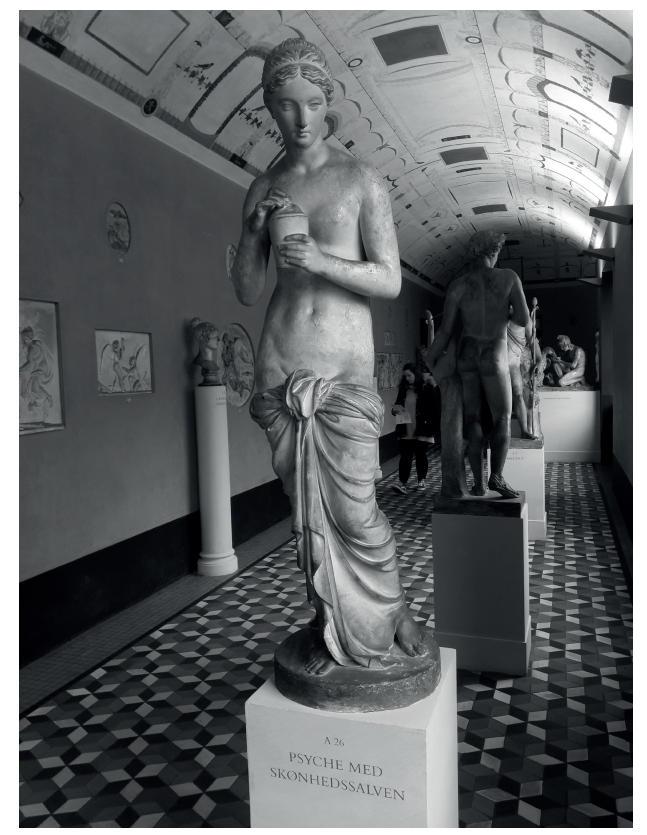

Illustrasjon 6. Bertel Thorvaldsen, Psyche, 1806, gips, 131,7 cm (foto: Åse Markussen) Kilde: Thorvaldsens Museum.

Malms Psyke vant ros, selv fra den store Bertel Thorvaldsen ${ }^{10}$, som kort trådde inn $\mathrm{i}$ «Malms historie» (og atelier) med ordene: «De har en smuk Fremtid for Dem» (Bergsøe 1988: 139).

$9 \quad$ Psyke betyr sjel, og er i gresk mytologi en personifisering av menneskesjelen. Hun fremstilles i den greske bildende kunst som en liten kvinneskikkelse med vinger, som en fugl eller en sommerfugl, ofte i forbindelse med erotene (amorinene) eller med Amor (Eros) (Kraggerud 2018).

10 Det er for øvrig vanskelig å slutte seg til Bache-Wiigs formening om at Bertel Thorvaldsen vokste opp på Island og derfor var «av samme norrøne malm som unggutten [Malm] fra Telemark» (Bache-Wiig 2018: 75). Han ble født i København; hans islandske far kom til Danmark alt som 17-åring og giftet seg med en jydsk kvinne. Thorvaldsen skal aldri ha besøkt Island. Som Europas førende klassisist med 40 år i Roma kan han etter mitt syn heller ikke ses som garantist «for en link mellom klassisk billedhoggerkunst og det nordiske», om det da ikke menes «de nordiske». Nordiske billedhuggere ble i svært sterk grad og i mer enn et halvt sekel påvirket av Thorvaldssen og hans nyklassisisme. Selv var han neppe nevneverdig preget av «det nordiske». 


\section{Kjellberg, Glosimodt og Malm-skikkelsen}

Frithiof Kjellberg nevnes gjerne i forbindelse med Malm-skikkelsen, og Bergsøe bekrefter jo selv at han brukte anekdoten om Kjellbegs fauner i «Malms historie» (se over). Utover dette tror jeg ikke den godmodige og muntre Kjellberg har gitt trekk til personen Malm.

Flere norske kilder har ment at Olaf Glosimodt var modellen til Malm. Einar Østvedt skrev i 1967 at Glosimodt kom i nær kontakt med Bergsøe i Roma, og at denne brukte "Glosimodt som modell for hovedpersonen Ole [sic] Malm» i «Malms historie» (Østvedt 1967: 42). Dette ble senere videreført av kunsthistorikerne Elisabeth Elster og Dag Sveen i henholdsvis Norsk biografisk leksikon og Norsk kunstnerleksikon (Elster 2020; Sveen 2013). Men kan dette stemme? Glosimodt ankom Roma sent i oktober 1861 og ble i ni måneder (Weilbach 1896-1897). Han forlot sannsynligvis byen og reiste tilbake til København i september 1862, da han avsluttet medlemskapet i Skandinavisk forening ${ }^{11}$. Bergsøe ankom Roma ved månedsskiftet november-desember $1862^{12}$. Riktignok var Glosimodt fra Telemark, men jeg tror ikke at Malms ankomst til Roma i «Thelemarkernes Dragt» nødvendigvis skal oppfattes bokstavelig. Det er heller det rotnorske Bergsøe ville fremheve, og det kan gjerne også være et av hans mange fargerike påhitt, kanskje inspirert av skulpturene i Nordmandsdalen ved Fredensborg Slot på Sjælland. Hverken Bergsøe eller Dietrichson har nevnt Glosimodt i sine erindringer fra Roma.

I artikkelen i Norsk biografisk leksikon leser Elster «Malms historie» som Bergsøes syn på «den norske bygdekunstners vanskelige livssituasjon i Roma». Dette er en noe snever tolkning av Malms skjebnedrama, og «bygdekunstner» neppe riktig betegnelse på en klassisk utdannet billedhugger som Malm. Den danske litteraturhistorikeren Paul V. Rubow har sett saken fra en annen vinkel. Han har ment å finne et forlegg for «Malms historie» i H.C. Andersens ovennevnte novelle Psychen, omdannet i en mer moderne romanform av Bergsøe (Rubow 1948: 36-40, 46). Det er ingen urimelig tolkning. I likhet med Malm ødela Andersens unge billedhugger i Psychen sine skulpturer, inntil han lyktes med en psyke med hans elskedes trekk. Den kastet han fortvilet i en brønn da hun vraket ham.

11 Skandinavisk forenings arkiv i Roma. Protokoll E1.

12 Bergsøe oppgir selv den 4. desember (Bergsøe 1905: 156). Rubow oppgir sist i november (Rubow 1948: 41). 


\section{7. «den unge Malm er vist nærmest gjort over en norsk Billehugger Budal»}

Rubow har behandlet Bergsøes Fra Piazza del Popolo to ganger. I 1937 skrev han at «den unge Malm er vist nærmest gjort over en norsk Billedhugger Budal» (Rubow 1937: 135). I 1948 skrev han imidlertid, uten nærmere begrunnelse, at «det af Bergsøes Erindringer nok kunde se ud, som om de norske Billedhuggere Fladager og Budahl [sic] har givet visse Kontributioner [til Malm]» (Rubow 1948: 36-40, 46). Han lanserte samme sted Holbech som modell for Malm i den siste delen av «Malms historie» som omhandler psyche.

Holbechs skulderbrede og kraftige skikkelse kan muligens ha vært modell for den eldre Malm som Fra Ambrosius ${ }^{13}$. Men jeg kan ikke se «Dydsforeningens president» Holbech i den unge Malm, og heller ikke Fladager, med dennes reisebrev fra Roma til nordisk presse, trygge atelierfellesskap med Bissens, og innflytelsesrike venner og hjelpere som Bjørnstjerne Bjørnson, Peter Andreas Munch og Johan Sebastian Welhaven. Det er etter mitt syn hos Hans Johnsen Budal at vi finner størst samsvar med Malm, både i biografi, begavelse og karaktertrekk (ill. 7). At Rubow brukte formuleringen «er vist nærmest gjort over» om Budal som modell for Malm, må etter mitt syn forstås som kjent viten og «noe man sa» i danske kretser, og ikke en slutning Rubow trakk i 1937. Om det er tradert gjennom mer enn et halvt sekel, bør det tillegges vekt.

Både Budal og Malm kom fra haugianske hjem, deres talent ble oppdaget av en fremmed fra Christiania, og de ble hjulpet til utdannelse. Begge var store begavelser som ble hemmet av mismot og selvkritikk. Karakteristisk var også uvirksomme perioder, tilbakeholdenhet, og en viss troskyldighet. Budals beskjedenhet var kjent, og både hans store talent og store beskjedenhet ble kommentert i Morgenbladet av Christiania Kunstforenings Emil Tidemand den 1. april 1860. Ved Budals død i Kristiania i 1879 ble hans rettskafne karakter og «et eiendommelig barnligt-troskyldigt og beskedent Sind» omtalt ([Notis] 1879). Dietrichson, som kjente Budal fra årene i Roma, beskrev ham i Svundne Tider som «en lys, freidig og livskraftig, skjønt kanskje lidt melankolsk yngling oppe fra Tydalsfjeldene, vistnok ikke mindre, snarere mere begavet end Mængden af de unge Kunstnere, der paa hin Tid laa i Rom». Han nevnte hans kraftige skikkelse og kalte ham «halvt en Balder, halvt en Frithjof» (Dietrichson 1901: 66-67). Budal viste tre skulpturer på den store Stockholmsutstillingen i 1866, og Dietrichson skrev i sin anmeldelse at: «Oss tycks Budals figurer vara det mest lofvande af de yngre norske konstnärernas arbeten vid siden af Middelthons [sic] nämnda byst [av Welhaven]» (Dietrichson 1866: 92).

$13 \quad$ Se note 9. 


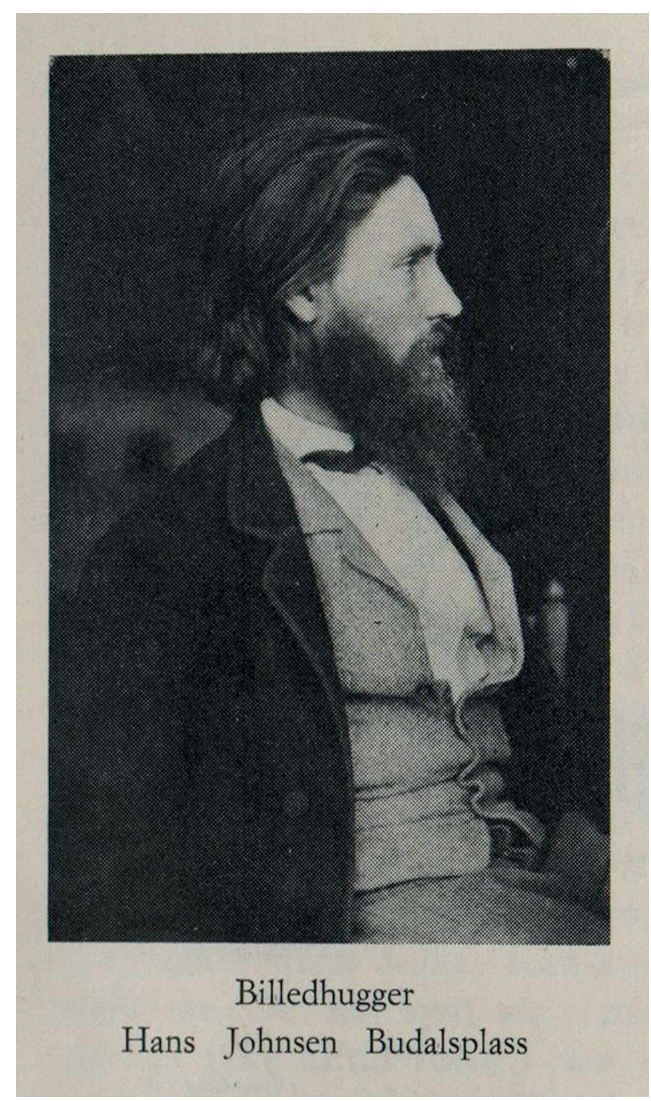

Illustrasjon 7. Fotografisk portrett av Hans Johnsen Budal (u.å., ant. København sist i 1850-årene)

Kilde: Bakken 1935: 581.

I «Malms historie» er vennskapet mellom Malm og «den Gamle af Dage» en rød tråd. Når «Den Gamle af Dage» beviselig bygger på Holbech, både med hensyn til utseende og karakter, er det ikke urimelig å tro at Malm i hovedsak bygger på Budal. Atelierfellesskapet og vennskapet mellom nykommeren Budal og veteranen Holbech støtter en slik teori.

Tegneskolen i Christiania brukte ikke medaljekonkurranser, og når Bergsøe lot Malm vinne «baade første og anden Priisbelønning og endelig det store Legat til Romerreisen», har han vel tenkt på det danske akademiets gullmedaljekonkurranser. I så fall passer ikke dette på Budal. Han konkurrerte aldri om gullmedaljene, selv om han vant både lille og store sølvmedalje ved første forsøk, noe de færreste oppnådde. Malms heftige gemytt, og vandringen til fots til Roma, er også elementer vi savner hos Budal, men finner hos Herman W. Bissen. 


\section{8. «Gamle Bissen» som den unge Malm?}

Akademiets gullmedaljer hang høyt. Herman W. Bissen vant både lille og store gullmedalje med akademiets treårige stipend til Roma. Dit gikk han i 1824 til fots fra München over Alpene.

At Bergsøe åpenbart brukte Bissens skulptur Den vrede Achilles i «Malms historie», betyr ikke at Bissen var modell for romanfiguren Malm. Men det er trekk i Malm-skikkelsen som passer nettopp på den store danske billedhuggeren, trekk vi for så vidt også ser hos Budal. Bissens biograf Haavard Rostrup skrev om «den sindets renhed, den kunstneruskyldighed, som han bevarede hele livet igjennem», og om «Denne grandiose naivitet [som] blev et grundlæggende træk i hans kunstneriske personlighed» (Rostrup 1945: 38). Akademiprofessor Bissens livshistorie og koleriske gemytt var neppe ukjent for Københavns borgerskap, og vel heller ikke for Bergsøe, som også kan ha hørt Bissen fortelle om sin første reise til Roma da de kort var der samtidig våren 1863.

Den dyrekjære Bissen fylte atelieret sitt i København med sydlige planter, fugler, firfirsler og skilpadder for å dempe lengselen etter Roma (Bloch 1927). I Malms første lykkelige tid i Roma gledet han seg over froskene i bassenget $i$ atelierets hage. Det kan ha moret Bergsøe å legge slike «bissenske» trekk til Malm-skikkelsen. Det er kanskje ikke tilfeldig at «Malms historie» foregikk nettopp innenfor perioden for Bissens første opphold i Roma mellom 1824 og 1834.

\section{En mulig konklusjon}

De fleste nøkkelpersonene i Bergsøe store roman ble raskt gjenkjent, og det skapte sensasjon i samtiden at flere av personene var hentet rett fra forfatterens omgangskrets i Danmark, lett kamuflert og med andre navn. Den samme soleklare gjenkjennelsen skjedde aldri med Olaf Malm. Malm-skikkelsen er mer tvetydig, og kan bygge på mer enn én person. Jeg tror Rubow traff rett da han i 1937 pekte på den norske billedhuggeren Hans Johnsen Budal som den viktigste modellen. Om vi supplerer med trekk av Herman W. Bissens personlighet og biografi, kan vi nærme oss Olaf Malm.

Om dette er riktig, gir det et verdifullt trekk til det sparsomme bildet vi har av kunstneren Budal. Norsk senklassisisme er foreløpig lite behandlet i kunsthistorien. «Malms historie» viser et lite snitt av miljø og atmosfære i Roma; et Roma Olaf Glosimodt forlot etter mindre enn et år, mens Hans Budal utviklet sitt kunstnerskap der gjennom hele ti år. Dietrichson viet et langt tekstavsnitt til Budal i Svundne tider. Kanskje var det noe eget ved den begavede og særegne Hans Budal som Dietrichson så, og som også ga Bergsøe impulser til Malm-skikkelsen.

Bergsøe kjente kunstnerne og atelierene rundt Piazza Barberini. Med sin store fantasi og uttrykkskraft har han hentet det han trengte i erindringene fra Roma, 
kombinert faktisitet og fiksjon, omformet og omdiktet, og skapt en Olaf Malm større enn virkeligheten. Like gjerne fra Slesvig som fra Telemark, men kanskje helst fra Budalen i Sør-Trøndelag i Norge.

Litteraturliste

Agger, G. (1994). Fra Piazza del Popolo og fortællingen som genre. KઐK: Kultur og Klasse. Kritik og Kulturanalyse 21(2 [76]): 111-136.

Andersen, H.C. (1862). Psychen. Nye Eventyr og Historier. Anden Række. Anden Samling. København: C.A. Reitzels.

[Anon]. (1879). Hans Budal. [Nekrolog]. Ny illustreret Tidende 13(6): 1.

Bache-Wiig, H. (2018). Olaf Malms historie. Om en skjebnefigur i Vilhelm Bergsøes roman Fra Piazza del Popolo. Studia Scandinavica 2(22): 65-77. DOI: https://doi.org/10.26881/ ss.2018.22.04.

Bakken, J. (1935). Billedhugger Hans Johnsen Budal. Gauldalsminne 10(1): 577-612.

Bergsøe, V. (1866). Fra Piazza del Popolo. Livsbilleder, samlede i Rom. København: Philipsen [1867 på tittelblad].

Bergsøe, V. (1877). Rom under Pius den niende. Skizzer og skildringer. København: Gyldendal. Bergsøe, V. (1905). Eventyr i udlandet. København: Gyldendal.

Bergsøe, V. (1988). Fra Piazza del Popolo. Novelle-cyklus 1-3. Serie: Danske Klassikere. Tekstudgivelse, noter og efterskrift ved F. Conrad og L.P. Røhmild. København: Det danske Sprog- og Litteraturselskab, Borgen.

Bloch, O. (1927). H.V. Bissen og hans Hjem. Breve og Erindringer 1857-1868. København: V. Pios Boghandel.

Dietrichson, L. (1866). Skandinaviska konst-expositionen i Stockholm 1866: Sverige, Norge, Danmark, Finland. Stockholm: L. Dietrichson.

Dietrichson, L. (1901). Svundne Tider: af en Forfatters Ungdomserindringer: 3: Rom og Stockholm: 1862-1872. Kristiania: Cappelen.

Dørum, K. (2021). Oppslagsord: haugianere. Store norske leksikon, https://snl.no/haugianere (tilgang: 5.06.2021).

Elster, E. (2020). Oppslagsord: Olaf Glosimodt. Norsk biografisk leksikon, https://nbl.snl.no/ Olaf_Glosimodt (tilgang: 30.05.2021).

Fladager, O. (1861). Af et brev fra Ole Fladager i Rom. Morgenbladet, 27. november 1861, s. 2.

Galschiøt, M. (1925). Skandinaver i Rom for halvhundred aar siden. København: M.P. Madsen.

Goldschmidt, M. (1863). Hvorledes man lever i Rom. I: M. Goldschmidt. Fortoellinger og Skildringer. B. 1. København: Steen, s. 22-46.

Kraggerund, E. (2018). Oppslagsord: Psyke. Store norske leksikon, https://snl.no/Psyke (tilgang: 27.05.2021).

Lindhagen, M.P. (2020). Oppslagsord: Lago di Nemi - Nemisjøen. Store norske leksikon, https:// snl.no/Lago_di_Nemi_-_Nemisj\%C3\%B8en (tilgang: 28.05.2021).

[Notis]. (1861). Morgenbladet, 17. november 1861.

[Notis]. (1871). Morgenbladet, 5. juli 1871.

Rohde, H.P. (1972). Digt og sandhed om en berømt roman. Piazza del Popolo i dokumentarisk belysning. Digt og forskning (19): 129-155.

Rostrup, H. (1945). H.W. Bissen. København: F. Bagges kgl. hofbogtrykkeri.

Rubow, P.V. (1937). Danske skribenter i Rom 1860-1900. I: L. Bobé (red.). Rom og Danmark gennem tiderne: 2. København: Levin \& Munksgaard.

Rubow, P.V. (1948). Vilhelm Bergsøe og hans store roman. København: Gyldendal. 
Sveen, D. (2013). Oppslagsord: Olaf Olafsen Glosimodt. Norsk kunstnerleksikon, https://nkl.snl. no/Olaf_Olafsen_Glosimodt (tilgang: 30.05.2021)

Thorvaldsens Museum. (2002). Afmagt: dansk billedhuggerkunst 1850-1900. København: Thorvaldsens Museum.

Thorvaldsens Museum. (2018). https://arkivet.thorvaldsensmuseum.dk/dokumenter/ea9526?highlight=Psyche (tilgang: 27.05 .2021 ).

Tidemand, E. (1860). [Om Hans Johnsen Budal]. Morgenbladet, 1. april 1860, s. 2.

Weilbach, P. (1896-1897). Oppslagsord: Glosimodt. Nyt dansk Kunstnerlexikon. 2. Udg, https:// wbis-degruyter-com.nb.idm.oclc.org/biographic-document/C48600 (tilgang: 30.05.2021).

Wilkens, C. (1924). Oppslagsord: Nøgleroman. Salmonsens Konversationsleksikon. 2. Udg. København: Schultz forlag.

Østvedt, E. (1967). Telemark i norsk billedhuggerkunst. Skien: Oluf Rasmussens forl. 